\title{
PEMBERDAYAAN MASYARAKAT DALAM MENINGKATKAN PENGETAHUAN DI BIDANG KEWIRAUSAHAAN, PEMASARAN DAN PUPUK ORGANIK DI KECAMATAN TANJUNG BATU
}

\author{
Oleh: \\ Rina Ratih, Ahmad Tahir, dkk \\ Universitas Ahmad Dahlan Yogyakarta
}

\section{Ringkasan}

Permasalahan yang ada di masyarakat Kecamatan Tanjung Batu, Kabupaten Ogan Ilir, Sumatera Selatan adalah 1) banyak terdapat tumpukan sampah dan limbah rumah tangga; dan 2) panjang nya rantai distribusi atas pemasaran produk kreatif masyarakat Tanjung Batu. Maka dilaksanakan program KKN yang difokuskan pada peningkatan pengetahuan di bidang kewirausahaan, pemasaran dan pupuk organik. Program ini bertujuan untuk memberdayakan masyarakat dalam pemanfaatan limbah rumah tangga dan memutus rantai distribusi produk kreatif masyarakat Tanjung Batu. Metode pelaksanaan program KKN meliputi: teori dan pelatihan kewirausahaan, pemasaran dan pupuk organik. Dampak dari kegiatan KKN ini adalah : 1) masyarakat menjadi lebih termotivasi untuk menjadi seorang wirausaha dan tidak memandang bahwa wirausaha adalah sebuah pekerjaan yang rendah; 2) peningkatan pengetahuan masyarakat dalam memasarkan produk kreatif nya dan dapat memutus rantai distribusi sehingga pendapatan atas penjualan produk menjadi lebih besar; 3) masyarakat dapat memahami pentingnya menjaga lingkungan dengan tidak membuah sampah sembarangan dan memanfaatkan serta mengolah sampah dan limbah rumah tangga menjadi pupuk organik yang dapat tetap menjaga kesuburan tanah dan memangkas input atas pembelian pupuk kimia.

Kata Kunci: sampah, kewirausahaan, limbah

\begin{abstract}
The problems that exist in the community of Tanjung Batu Subdistrict, Ogan Ilir Regency, South Sumatra are 1) there are many piles of garbage and household waste; and 2) the length of its distribution chain on marketing of creative products of Tanjung Batu people. So implemented the KKN program which focused on increasing knowledge in the field of entrepreneurship, marketing and organic fertilizer. This program aims to empower the community in the utilization of household waste and break the distribution chain of creative products of Tanjung Batu people. Methods of KKN program implementation include: entrepreneurship theory and training, marketing and organic fertilizer. The impacts of these KKN activities are: 1) society becomes more motivated to become an entrepreneur and does not perceive that entrepreneurship is a low job; 2) increasing the knowledge of the community in marketing its creative products and can break the distribution chain so that the revenue on the sale of the product becomes larger; 3) the public can understand the importance of maintaining the environment by not littering and utilizing and processing waste and household waste into organic fertilizer that can keep the soil fertility and cut input on the purchase of chemical fertilizers.
\end{abstract}

Keywords: waste, entrepreneurship, waste 


\section{A. PENDAHULUAN}

Kecamatan Tanjung Batu merupakan salah satu kecamatan yang berada di Kabupaten Ogan Ilir, Provinsi Sumatra Selatan. Kecamatan Tanjung Batu ini memiliki luas wilayah $26.375 \mathrm{Ha}$ dan memiliki 21 desa. Jumlah penduduk 44.415 jiwa dengan persentase penduduk perempuan 50,6 persen dan laki-laki 49,4 persen. Kecamatan Tanjung Batu memiliki iklim tropis basah dan dialiri oleh salah satu sungai besar yaitu sungai ogan. Tekstur tanah di Kecamatan Tanjung Batu subur dan ketersediaan air sangatlah melimpah. akses untuk memenuhi kebutuhan sehari hari masyarakat Tanjung Batu sangatlah mudah dikarenakan kebutuhan bahan pokok masih melimpah dan akses untuk mendapatkan ikan sangatlah mudah karena danau atau sungai yang di setiap desa masih terdapat banyak ikan dan menjadi sumber mata pencaharian masyarakat.

Disamping potensi sumber daya alam yang melimpah, Tanjung Batu memiliki banyak potensi industri yang berkembang di tengah masyarakat. Berdasarkan sensus ekonomi pada 2005 di Kecamatan Tanjung Batu merupakan paling banyak industri kecil dan menengah (IKM) dengan total jumlah usaha 4.538 yang memiliki bangunan usaha dan 1.453 usaha yang berpindah-pindah atau keliling. Potensi tersebut mulai dari pengrajin kain songket, pandai besi, pandai emas, rumah knock down, dan industri kreatif lainnya. Potensi pengrajin yang melimpah tidak di imbangi dengan kemampuan dalam memasarkan produknya, sehingga menciptakan rantai distribusi (distribution chain) yang cukup panjang.

Kecamatan Tanjung Batu belum memiliki Tempat Pembuangan Akhir (TPA) sampah, sehingga menyebabkan banyak tumpukan sampah di belakang rumah warga. Pandangan masyarakat tentang sampah merupakan barang yang tidak berharga dan bahkan menyebabkan pencemaran lingkungan. Padahal sampah dapat dimanfaatkan dan diolah menjadi pupuk organik yang sangat berguna untuk perkebunan yang dimiliki warga. Potensi alam yang melimpah dengan tanah yang subur dan terdapat perkebunan warga dapat menjadikan pupuk organik menjadi pengganti pupuk berbahan kimia.

Potensi Kecamatan Tanjung Batu disamping menjadi sebuah keunggulan namun menciptakan sebuah masalah baru, yaitu: 1) pengatahuan masyarakat dalam memasarkan produk kerajinan kreatif nya masih sangat sedikit; dan 2) pengatahuan masyarakat tentang cara pengelohan limbah rumah tangga menjadi pupuk organik masih terbatas.

Berdasarkan permasalahan tersebut, maka dilaksanakan sebuah program Kuliah Kerja Nyata Muhammadiyah untuk Negeri (KKN Mu) dalam bentuk teori dan pelatihan untuk dapat meningkatkan pengetahuan masyarakat dalam hidup sehat dan pengelolaan sampah serta menghasilkan sampah organik serta mampu memasarkan hasil produksi, memutus rantai distribusi dan melahirkan pelaku-pelaku usaha baru untuk mendorong terserapnya lebih banyak tenaga kerja yang dapat meningkatkan taraf hidup masyarakat.

\section{B. METODE PELAKSANAAN}

Untuk mencapai tujuan yang diharapkan, program KKN di Tanjung Batu dilakukan dengan pemberdayaan masyarakat melalui seminar untuk peningkatan pengetahuan masyarakat di bidang kewirausahaan, pemasaran dan pelatihan pembuatan pupuk organik 
Diterbitkan oleh Lembaga Pengabdian kepada Masyarakat

Universitas Ahmad Dahlan Yogyakarta

secara langsung. Ringkasan metode pelaksanaan beserta jam kerja efektif mahasiswa (JKEM) tersaji pada table I.

Tabel 1. Metode, Kegiatan, JKEM dan keterlibatan mahasiswa

\begin{tabular}{|c|c|l|c|c|}
\hline No & Metode & \multicolumn{1}{|c|}{ Kegiatan } & JKEM & $\begin{array}{c}\text { Jumlah } \\
\text { mahasiswa } \\
\text { yang terlibat }\end{array}$ \\
\hline 1 & Teori & $\begin{array}{l}\text { Menyelenggarakan seminar tentang } \\
\text { menjadi wirausahawan }\end{array}$ & $1 \times 2$ jam & 30 \\
\cline { 3 - 5 } & $\begin{array}{l}\text { Menyelenggarakan seminar tentang } \\
\text { pemasaran global dan lokal }\end{array}$ & $1 \times 2 \mathrm{jam}$ & 30 \\
\cline { 3 - 5 } & $\begin{array}{l}\text { Menyelenggarakan seminar menjaga } \\
\text { lingkungan dan pembuatan pupuk } \\
\text { organik cair }\end{array}$ & $1 \times 2 \mathrm{jam}$ & 30 \\
\hline 2 & Praktek & $\begin{array}{l}\text { Pelatihan Pembuatan Pupuk Organik } \\
\text { Cair dari sampah dan limbah rumah } \\
\text { tangga }\end{array}$ & $1 \times 2$ jam & 30 \\
\hline
\end{tabular}

\section{PEMBAHASAN}

\section{Potensi Kecamatan Tanjung Batu}

a. Kewiraushaan dan Pemasaran

Tanjung Batu merupakan kecamatan yang memiliki pelaku usaha terbanyak di Kabupaten Ogan Ilir berdasarkan sensus ekonomi pada tahun 2005. Tingginya jumlah pelaku ekonomi menjadi keunggulan komparatif (comparative advantage) untuk Tanjung Batu. Industri pengolahan (manufacturing)_yang terdapat di Tanjung Batu sangat bervariatif, mulai dari industri kain songket, pandai besi, pandai emas, alumunium dan rumah knock down.

Tabel 2. Jumlah Perusahaan/Usaha Menurut Lapangan Usaha yang mempunyai

Bangunan Tetap per Desa / Kelurahan di Kecamatan Tanjung Batu 2015

\begin{tabular}{clccccc} 
No & Desa/Kelurahan & $\begin{array}{c}\text { Industri } \\
\text { Pengola } \\
\text { han }\end{array}$ & Kontruksi & $\begin{array}{c}\text { Perdagang } \\
\text { an Besar } \\
\text { dan eceran }\end{array}$ & $\begin{array}{c}\text { Akomodasi } \\
\text { dan makan } \\
\text { minuman }\end{array}$ & $\begin{array}{c}\text { Real Estate, } \\
\text { Usaha } \\
\text { Persewaan }\end{array}$ \\
\hline$(1)$ & \multicolumn{1}{c}{$(2)$} & $(3)$ & $(4)$ & $(5)$ & $(6)$ & $(7)$ \\
\hline 1 & Seri Bandung & 12 & 191 & 134 & 23 & 39 \\
2 & Seri Tanjung & 70 & 0 & 104 & 16 & 22 \\
3 & Bangun Jaya & 8 & 0 & 56 & 13 & 0 \\
4 & Tanjung Tambak & 7 & 2 & 24 & 1 & 0 \\
& Tanjung Baru & & & & 5 & 12 \\
5 & Petai & 21 & 110 & 29 & & 1 \\
& Tanjung Batu & 0 & 114 & 17 & 0 & 0 \\
6 & Seberang & 200 & 24 & 40 & 4 &
\end{tabular}




\begin{tabular}{clccccc}
8 & Limbang Jaya I & 280 & 1 & 22 & 4 & 0 \\
9 & Tanjung Laut & 312 & 0 & 10 & 0 & 0 \\
10 & Tanjung Pinang I & 400 & 3 & 33 & 5 & 0 \\
11 & Tanjung Batu & 238 & 41 & 90 & 14 & 14 \\
12 & Pajar Bulan & 6 & 0 & 28 & 2 & 0 \\
13 & Senuro Timur & 3 & 1 & 30 & 2 & 1 \\
14 & Sentul & 0 & 0 & 15 & 1 & 1 \\
15 & Burai & 94 & 0 & 19 & 0 & 0 \\
& Tanjung Batu & & & & & 6 \\
16 & Timur & 200 & 40 & 39 & 12 & 0 \\
& Tanjung Tambak & & & & & 0 \\
17 & Baru & 5 & 1 & 22 & 0 & 0 \\
18 & Limbang Jaya II & 217 & 0 & 10 & 0 & 0 \\
19 & Senuro Barat & 1 & 0 & 27 & 0 & 0 \\
20 & Tanjung Pinang II & 336 & 0 & 20 & 3 & 110 \\
& Tanjung Atap & & & & & 0 \\
21 & Barat & 184 & 14 & 36 & 3 & 108 \\
\hline & Jumlah & 2594 & 542 & 805 & & \\
\hline
\end{tabular}

Sumber: Tanjung Batu dalam Angka 2016

Berdasarkan tabel 2 jumlah perusahaan/usaha di Tanjung Batu memberikan informasi bahwa Tanjung Batu memiliki pelaku usaha tertinggi di Kabupaten Ogan Ilir. Tingginya jumlah pelaku usaha memberikan dampak positif bagi masyarakat sehingga masyarakat memiliki pekerjaan dan menjadi produktif serta mampu menghasilkan suatu produk untuk meningkatkan pendapatan perkapita nya.

Pelaku usaha tertinggi adalah bidang industri pengolahan dengan jumlah pelaku usaha 2594 usaha. Pelaku industri terbanyak terdapat di Desa Tanjung Pinang dengan 400 usaha dan Tanjung Pinang 2 dengan 336 usaha. Industri yang terdapat di Tanjung Pinang 1 dan Tanjung Pinang dua paling banyak adalah pandai besi dan kain songket, dua industri tersebut berpusat di desa tersebut. Desa Tanjung Laut dan Limbang Jaya 1 memiliki pelaku usaha industri pengolahan terbanyak selanjutnya yaitu sebanyak 312 dan 280 usaha, desa tersebut menghasilkan produksi yang serupa dengan Tanjung Pinang 1 dan Tanjung Pinang 2 tetapi berbeda dalam segi bentuk dan motif yang dihasilakan. Berbeda dengan Desa Tanjung Batu dan Tanjung Atap, dimana mereka memiliki usaha terbanyak dibidang pandai besi dan pandai alumunium. Konsep industri yang terdapat di Kecamatan Tanjung Batu memiliki konsep aglomerasi, yaitu industri terkonsentrasi dan terbagi-bagi.

Terdapat pelaku usaha kontruksi di Tanjung Batu sejumlah 542 pelaku usaha, terbanyak terletak di desa Seri Bandung sejumlah 191, Tanjung Atap Seberang sejumlah 114 dan Tanjung Petai Baru sejumlah 110. Pedagang besar dan eceran di Tanjung Batu terdapat 805 pelaku usaha dan terbanyak berada di desa Seri Bandung. Usaha akomodasi dan makan minuman dan real estate \& 
persewaan di Tanjung Batu terdapat 108 dan 110 pelaku usaha. Jumlah pelaku usaha dari ke lima jenis usaha industri pengolahan, kontruksi, pedagang besar eceran, akomodasi makan minuman dan real estate di Kecamatan Tanjung Batu terdapat sejumlah 4.159 pelaku usaha pada tahun 2015.

Rasio jumlah penduduk dengan pelaku usaha pada tahun 2015 adalah (4.159 / 44.415 ) jiwa adalah 9,36\%, artinya jumlah pelaku usaha sebesar 9,36 $\%$ dari jumlah penduduk 44.415 jiwa. Jumlah pelaku usaha sudah cukup tinggi jika dibandingkan dengan jumlah penduduk. Berdasarkan keunggulan yang dimiliki oleh Tanjung Batu tersebut dapat dijadikan Kecamatan Tanjung Batu sebagai sentra produksi di Kabupaten Ogan Ilir dengan terus meningkatkan jumlah pelaku usaha industri kecil menengah (IKM) dan mendukung usaha mikro kecil menengah (UMKM).

\section{b. Pupuk Organik}

Tanjung batu juga memiliki perkebunan dan pertanian yang dapat dijadikan sebagai komoditas dan menyedot banyak tenaga, sehingga dapat memberikan dampak yang baik terhadap perekonomian dan pendapatan perkapita masyarakat tanjung batu. Berikut adalah beberapa komoditas perkebunan di Tanjung Batu selain perkebunan tebu, perkebunan karet dan perkebunan sawit.

Tabel 3. Penjabaran Luas Komoditas Buah-buahan menurut dalam Kecamatan Tanjung Batu 2015

\begin{tabular}{llccccc}
\hline \multirow{2}{*}{ No } & \multirow{2}{*}{ Desa/Kelurahan } & \multicolumn{5}{c}{ Nama Buah (Ha) } \\
\cline { 2 - 7 } & & Nanas & Jeruk & Semangka & Rambutan & Pisang \\
\hline 1 & Seri Bandung & 25 & - & - & - & - \\
2 & Seri Tanjung & - & - & - & - & - \\
3 & Bangun Jaya & - & - & - & - & - \\
5 & Tanjung Tambak & 35 & - & 10 & 14 & - \\
6 & Tanjung Baru Petai & 10 & 3 & - & - & - \\
7 & Tanjung Batu Sebrang & 2 & - & 2 & - & - \\
8 & Tanjung Atap & - & - & - & - & - \\
9 & Limbang Jaya I & - & - & - & - & - \\
10 & Tanjung Laut & - & - & - & - & - \\
11 & Tanjung Pinang I & - & 5 & - & - & - \\
12 & Tanjung Batu & 11 & 4 & 17 & 4 & - \\
13 & Pajar Bulan & 25 & - & - & - & - \\
14 & Senuro Timur & 50 & 4 & - & - & - \\
15 & Sentul & 120 & - & 13 & - & - \\
16 & Burai & 10 & - & - & 5 & 2 \\
17 & Tanjung Batu Timur & - & - & - & - & - \\
18 & Tanjung Tambak Baru & 35 & - & - & - & - \\
19 & Limbang Jaya II & - & - & - & - & - \\
20 & Senuro Barat & 60 & 2 & - & - & - \\
21 & Tanjung Pinang II & - & 2 & - & - & - \\
& & & & & &
\end{tabular}


22 Tanjung Atap Barat

\begin{tabular}{llllll} 
Jumlah & 383 & 20 & 42 & 23 & 2 \\
\hline
\end{tabular}

Berdasarkan data diatas Tanjung Batu memiliki luas lahan perkebunan seluas $470(\mathrm{Ha})$ hektar. Lahan perkebunan yang terluas adalah perkebunan nanas dengan luas lahan $383 \mathrm{Ha}$ atau setara dengan $81 \%$ perkebunan buah didominasi oleh perkebunan nanas. Tanjung Batu merupakan daerah memiliki penghasilan nanas lebih besar dari pada komoditas buah lain. Seperti jeruk, semangka, rambutan dan pisang hanya memiliki luas lahan sebesar $20 \mathrm{Ha}, 42 \mathrm{Ha}, 23 \mathrm{Ha}$ dan 2 Ha.

Terdapat komoditas sayur-sayuran yang ditanam cukup beragam. Selain tanaman tebu, tanaman karet juga cukup banyak dibudidayakan dengan luas Tanam 3457 Ha di tahun 2014 tidak berubah dibandingkan tahun 2013, Selain tanaman tebu dan karet, tanaman lainnya yang diproduksi yaitu tanaman kelapa sawit rakyat dengan luas hanya 20 ha, yaitu hanya di Desa Senuro.

Perkebunan merupakan komoditas yang membutuhkan nutrisi atau pupuk untuk merawat tanaman dan untuk menghasilkan buah yang lebih baik dan lebih banyak. Penggunaan pestisida kimia yang marak dilakukan saat ini sebenarnya tidak lah baik dan dapat memangkas usia tanaman menjadi lebih pendek dan juga dapat merusak tanah. Perlunya pupuk organik yang dapat dibuat dan mudah untuk dihasilak menjadi salah satu alternatif untuk menjadikan bahan organik sebagai nutrisi alami yang akan memberikan pertumbuhan yang baik pada tanaman, menghasilkan buah yang sehat dan terhindar dari pertisida kimia dan tetap mempertahankan kesuburan tanah menjadi pilihan alternatif.

Pupuk organik merupakan bahan yang berasal dari sisa-sisa tanaman, hewan, seperti pupuk kandang, kompos, pupuk hijau, jerami, dan bahan lain yang dapat berperan memperbaiki sifat fisik, kimia dan biologi tanah. Bahan organik tidak dapat menggantikan peran dari pupuk anorganik sebagai pemasok hara, karena kandungan unsur hara dalam bahan organik relatif rendah, namun demikian bahan organik dapat meningkatkan efisiensi penggunaan pupuk anorganik (Soedardjo dan Mashuri, 2000 dalam Sedjati, 2005).

Permasalahan yang terdapat di Tanjung Batu seperti sampah yang menumpuk dan tidak terdapatnya tempat pengelolaan sampah dapat dijadikan satu alternatif untuk memanfaatkan sampah dan memproduksi menjadi pupuk organik. Pupuk organik akibat dari pembuangan sampah atau sisa-sisa konsumsi dapat dijadikan bahan untuk membuat pupuk organik. Melalui pelatihan pembuatan pupuk organik tersebut dapat memberikan penyelesaian terhadap permasalahan sampah yang membuat resah masyarakat dan akan memberikan nilai ekonomi dari sampah menjadi pupuk organik dan dapat mengurangi anggaran untuk membeli pestisida kimia dan mengalihkannya untuk menambah kuantitas dan kualitis benih yang akan ditanam. 


\section{Gambaran Pelaksanaan}
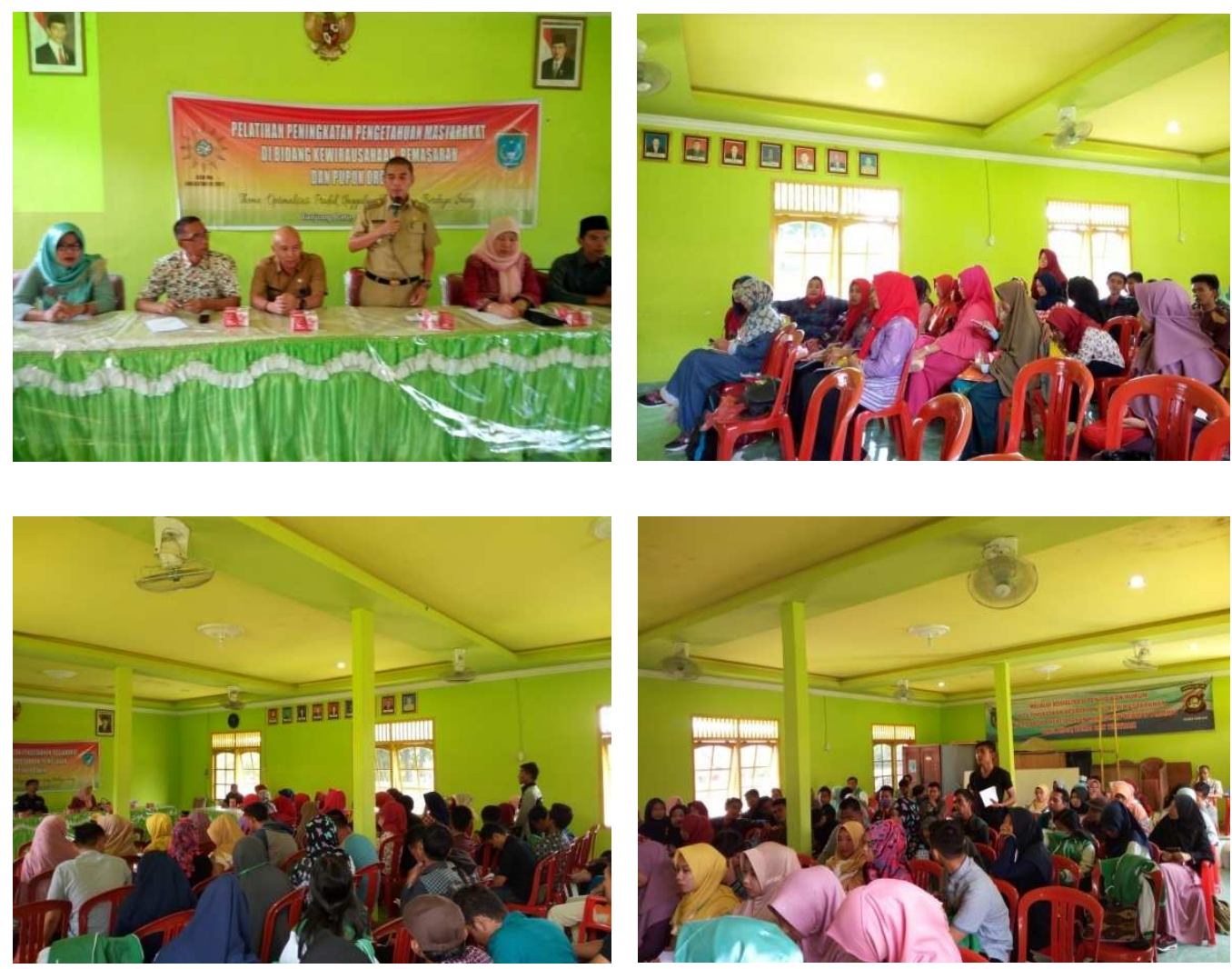

Gambar 1. Pelatihan Peningkatan Pengetahuan Masyarakat di Bidang Kewirausahaan, Pemasaran dan Pupuk Organik

Jumlah peserta yang mengikuti pelatihan adalah 80 peserta dari masyarakat yang diselenggarakan oleh Dinas Kesehatan dan Dinas Pemberdayaan Masyarakat Desa yang bertempat di Kantor UPT Dinas Pendidikan Tanjung Batu. Gambar diatas menunjukkan tinggi nya antusiasme masyarakat Tanjung Batu untuk mengikuti pelatihan yang dilaksanakan oleh Mahasiswa KKN Mu. Artinya program tersebut berjalan dengan baik dan pemberdayaan masyarakat berjalan dengan partipasi masyarakat yang tinggi. Dampak dari kegiatan KKN ini adalah : 1) masyarakat menjadi lebih termotivasi untuk menjadi seorang wirausaha dan tidak memandang bahwa wirausaha adalah sebuah pekerjaan yang rendah; 2) peningkatan pengetahuan masyarakat dalam memasarkan produk kreatif nya dan dapat memutus rantai distribusi sehingga pendapatan atas penjualan produk menjadi lebih besar; 3) masyarakat dapat memahami pentingnya menjaga lingkungan dengan tidak membuah sampah sembarangan dan memanfaatkan serta mengolah sampah dan limbah rumah tangga menjadi pupuk organik yang dapat tetap menjaga kesuburan tanah dan memangkas input atas pembelian pupuk kimia.

\section{KESIMPULAN}

Program KKN Mu dalam memberdayakan masyarakat di Kecamatan Tanjung Batu, Kabupaten Ogan Ilir, Sumatera Selatan untuk peningkatan pengetahuan di bidang 
kewirausahaan, pemasaran dan pupuk organik dapat berjalan dengan baik. Pemerintah Kecamatan Tanjung Batu diharapkan dapat melakukan monitoring dan evaluasi serta melakukan pendampingan dalam menciptakan lingkungan sehat yang bebas dari pencemaran lingkungan; meningkatkan jumlah wirausahawan muda dengan memberikan kemudahan terhadap akses perizinan serta memberikan pelatihan untuk meningkatkan soft skill; memberikan pendampingan kepada wirausahawan dalam memasarkan produk kreatif nya dan memfasilitasi dalam memutus rantai distribusi sehingga dapat meningkatkan pendapatan wirausahawan.

\section{DAFTAR PUSTAKA}

Badan Pusat Statistik Kabupaten Ogan Ilir. Kabupaten Ogan Ilir Dalam Angka 2016.

Badan Pusat Statistik Kabupaten Ogan Ilir. Statistik Daerah Kecamatan Tanjung Batu 2016.

Badan Pusat Statistik Kabupaten Ogan Ilir. Kecamatan Tanjung Batu Dalam Angka 2016.

Sedjati, Subur. Kajian Pemberian Bokashi Jerami Padi dan Pupuk Pada Kaca Tanah (Arachis hypogaea L.). 